\title{
FALANDO DE POESIA: \\ ENTREVISTA COM O POETA PEDRO TIERRA ${ }^{1}$
}

\author{
Eliane Cristina Testa ${ }^{2}$ \\ Paulo Aires Marinho ${ }^{3}$
}

Pedro Tierra é o pseudônimo do poeta e político tocantinense Hamilton Pereira da Silva (Porto Nacional, 1948). Nos anos de chumbo da ditadura militar brasileira, militou junto à Aliança Libertadora Nacional (ALN), tendo como consequências a prisão e a tortura. Na prisão, começou a compor os primeiros versos, enviados clandestinamente para publicação na Itália. Dessa produção resultou Poemas do povo da noite, que ganhou menção honrosa no Prêmio Casa de las Américas (1978). Atua junto ao Partido dos Trabalhadores, tendo comandado, em 2011, a Secretaria de Cultura do Distrito Federal. Em 2013, recebeu o título de Doutor honoris causa da Universidade Católica de Brasília e, em 2014, pela Universidade Federal do Tocantins.

Publicou ainda Missa da Terra sem males, com Pedro Casaldáliga e Martin Coplas (1979), Missa dos Quilombos, com Pedro Casaldáliga e Milton Nascimento (1981), Água de Rebelião (1983), Inventar o Fogo (1986), Passarinhar (1992) e Bernardo Sayão e o Caminho das onças (1997) e A palavra contra o muro (2013).

A entrevista que apresentamos foi realizada em Araguaína, por ocasião do I Colóquio de Arte \& Educação, promovido pelo Curso de Letras da Universidade Federal do Tocantins, em novembro de 2016, quando Tierra lançou seu livro de poemas intitulado A Estrela Imperfeita.

Em 2017, a EntreLetras publicou um poema inédito de Pedro Tierra que fala diretamente do contexto político do país: Contra seu ventre, nascemos... (Poema para ser lido em voz alta nas vigílias da democracia).

\section{Pedro, como aquele menino da Rua do Cabaçaco, de Porto Nacional, se fez poeta?}

Numa página de Simone de Beauvoir lemos "Não se nasce mulher. Torna-se mulher". Talvez seja possível dizer o mesmo com relação a se fazer poeta... No Brasil, o senso comum diz que ser poeta "é um dom..." no sentido de que é uma dádiva. Um privilégio. E nos encarrega de enfeitar com palavras, a vida. Mas poderia também ser interpretado como uma "condenação..."

\footnotetext{
${ }^{1}$ Foto da capa: Lia Testa, 2016.

${ }^{2}$ É professora de Literatura Portuguesa do Curso de Letras, da Universidade Federal do Tocantins - UFT, do Câmpus de Araguaína, do Programa de Pós-Graduação em Letras: Ensino de Língua e Literatura - PPGL/UFT e do ProfLetras da UFT. É poeta e artista visual. E-mail: poetisalia@gmail.com

${ }^{3}$ Servidor da Universidade Federal do Tocantins - UFT, do Câmpus de Palmas, poeta, contista e romancista.
} 
Um dever de por em palavras o belo e o terrível dos dramas que nos cercam. Gosto de pensar que o melhor caminho é relacionar o fazer poesia com trabalho. Esforço. Tenacidade. Trabalho no sentido de empregar horas, dias, anos, jornadas de tempo para ler, escrever, aprimorar certa sensibilidade para lidar com essas criaturas esquivas que são as palavras. O menino da Rua do Cabaçaco bebeu, sem se dar conta, a beleza, a liberdade, o ridículo dos pequenos poderes... e dos grandes, as tragédias, a mesquinhez e a grandeza humanas e busca quotidianamente vestilas com palavras.

\section{O livro "Poemas do povo da noite" nasceu nos cárceres da ditadura militar. Os} poemas foram exilados para a Europa para depois voltarem ao Brasil. Neste livro, percebemos o rigor da palavra e a força contundente dos dramas humanos. Como é possível escrever em momentos de dor sem perder de vista o trato com a linguagem, com a palavra?

A questão que você me propõe tem a ver com um desafio permanente: ao contrário do que se imagina, "a indignação é má conselheira ao se escrever um poema”. O dilema é: você quer escrever um poema ou um panfleto? Como distinguir um do outro? O poema tem mais chance de sobreviver ao imediato. As diferentes culturas do mundo giram, em geral, em torno de uma grande narrativa em geral escrita em verso: A Ilíada e a Odisseia, a Bhagavad Gita, o Popol Vuh, as Sagas Nórdicas, a Divina Comédia, Os Lusíadas. São criações duradouras. Diferentemente delas, raros são os panfletos que alcançam durabilidade. Neste momento, me recordo de um: O Manifesto Comunista, escrito por Marx e Engels, em 1848 que comoveu e comove ainda hoje parcelas consideráveis de homens e mulheres no mundo.

Entre nós, o Movimento Modernista de 1922, a meu juízo, representou uma espécie de segunda maturidade na literatura brasileira e resultou num salto fantástico na qualidade da poesia que se escreveu a partir dali. Mas produziu também um efeito colateral, digamos, indesejável: a libertação do verso preso pela ourivesaria parnasiana e a vertigem da viagem para o verso branco e logo para o verso livre permitiram em muitos brotar a ilusão de que enfileirar frases uma sobre a outra fazia de alguém um poeta... E tivemos safras sobre safras de discursos políticos, de sermões edificantes que aspiravam ser lidos como poemas. Em tempos de opressão como aqueles em que foram escritos os Poemas do Povo da Noite, é preciso ter mão firme e entender a lição de Mallarmé: "Poesia não se escreve com sentimentos, se escreve com palavras". 


\section{O crítico literário Alceu Amoroso Lima, Tristão de Athayde, afirmou que você estaria} para o Brasil dos anos de chumbo assim como Federico Garcia Lorca estava para a Espanha franquista. Que diálogo você faria entre sua poesia daquele período e a obra do poeta andaluz?

A partir desse generoso comentário do mestre Tristão de Athayde, escrevi, há muitos anos um breve texto: "Diálogos com Federico". Nele há um parágrafo que sintetiza aquilo que Tristão de Athayde identificou: "Os fascismos todos se parecem. Inicio esse diálogo cheio de armadilhas, sem vislumbrar precisamente onde chegaremos ao final do percurso. Imaginei um labirinto, um diálogo submerso, habitado por peixes e pássaros repetidos em espelhos, relógios cegos, desertos - tão ao gosto dos surrealistas - entre dois tempos mediados por um oceano e quarenta anos de tirania." Mais adiante, pensando sobre a poesia de Federico: "La luna, los cavalos, el água, Cordoba, Sevilha, los gitanos, los toros, el amor afuera de los códigos, los cuchillos, la muerte. Aí está Federico. Límpido. Moreno e claro. Imprevisto porque fundiu a força explosiva da poesia popular andaluz e conteve, com mão estrita de toureiro da palavra, a expressão máxima do verso. Há nele algo insuportavelmente matinal que nos desarma. Gratuito, agreste, infantil. Como as cores de Miró. Carrega no texto e no gesto a beleza e a brutalidade humanas. Não precisou, por isso, de afastar-se do universo poético e buscar o artifício da retórica. Nisso ele foi toureiro, sempre, experimentando a vida no limite extremo do risco, sempre tocando a fímbria da morte. Não a morte metafórica. A morte mesma, a densa morte irremediável. Crua. Sem retorno”. Federico foi fuzilado pela Falange em 1936, aos 38 anos. Os anjos morrem jovens. Por isso são eternos...

Lorca realizou com sua poesia uma conquista duradoura para a língua espanhola, conseguiu: "fundir o romance narrativo com o lírico, algo que na poesia espanhola culta não se havia conseguido em grau de beleza e misterioso cálculo que ele alcança” registra Mario Hernandez na sua Introdução ao Romancero Gitano. Talvez em meu benefício - e em benefício da generosidade de Tristão de Athayde - possa se identificar no Brasil profundo (afinal ambos somos ibéricos...) uma raiz comum, por exemplo no poema narrativo "A memória do Anjo", incluído no pequeno volume "Dies Irae" e o poema "Aluado" no livro "O Porto Submerso".

4. Em 1981, o jornalista Cláudio Abramo, ao ler o "Poemas do povo da noite", escreveu um testemunho na Folha de S. Paulo: “...comprei um livro de um jovem, Pedro Tierra, 
um livro que me fez as lágrimas brotarem dos olhos, tal a sua força. Ninguém fala desse jovem, em quem se reconhece desde logo o tom de um grande poeta da dor e do sofrimento, um grito contra a tortura que sofreu porque o Brasil me parece um país que cada vez mais dá as costas a si próprio. Gostaria de mostrar os versos de Pedro Tierra a Giuseppe Ungaretti, a T. S. Eliot, a Stephen Spender!” A obra do Pedro Tierra continua ignorada pelas grandes editoras e por expressiva parte dos brasileiros. Pedro, na sua opinião, a que se deve isso?

$\mathrm{Lia}^{4}$, seguramente não sou um poeta comercial... Meus livros em geral abordam temas indigestos. Lutas de perseguidos políticos, comunidades indígenas, negros, peões, sem-terra, o povo da rua, não são assuntos muito atrativos. Não vai aqui uma crítica aos editores. Confesso uma baixa capacidade de desempenho na divulgação do que escrevo... num país em que a poesia, desafortunadamente, não ocupa espaço relevante na formação das pessoas. Como diria Drummond sigo sendo "um poeta municipal", talvez "um poeta estadual" aspirando me tornar um "poeta federal”... afinal ainda estou no começo da carreira...

\section{Na sua trajetória de poeta e de leitor, quais os principais autores permanecem ao} primeiro alcance dos seus olhos?

Drummond, seguramente, tem sido o poeta que mais me acompanhou na vida. Desde a juventude, a militância, nos anos de prisão, quando em cela solitária, repetia os poemas que guardara na memória, para não ficar sozinho. Os brasileiros, particularmente os do século XX: Bandeira, Vinicius, João Cabral, Cecília, Adélia, Manoel de Barros. Grande Sertão: Veredas é a maior realização poética em língua portuguesa, desde Camões. Não importa que tenha sido escrita em prosa. Fernando Pessoa, sempre. Tenho sobre minha mesa o livro "Mensagem", uma antologia comovente. Os espanhóis: Machado, Lorca, Hernandez, Alberti, Cernuda. Os hispano-americanos: Soror Juana Inés de la Cruz, Neruda, Benedetti, Juan Gelman, Octávio Paz, Arguedas, Vallejo, Borges (de quem prefiro a prosa), Szpunberg, Cintio Vitier. Os anglosaxões Walt Whitman, "Folhas de Relva" é um livro seminal e a poesia do irlandês Dylan Thomas. Fico por aqui.

\footnotetext{
${ }^{4}$ Eliane Testa também conhecida como Lia Testa (nome artístico e adotado por afetividade familiar)
} 
6. Você sempre uniu literatura e militância política numa comunhão indissolúvel. É certo também que você compõe uma geração de poetas que não se exilaram das lutas e causas coletivas. Como vê o papel dos artistas no atual contexto político da América Latina e notadamente do Brasil?

Avalio que depois de trinta anos de esforços por construir sociedades democráticas em nossos países, voltamos à resistência. Estamos diante da circunstância de voltar a criar literatura, poesia, arte, cultura de resistência como no período em que a opção do Império foi nos impor ditaduras fardadas no continente. E vagamos durante anos entre a Revolução e o suicídio... Os métodos se modificaram para que a opressão e a espoliação permaneça. Hoje somos confrontados com o poderio do Império que necessita urgentemente de energia barata e segura: por isso golpearam a democracia brasileira que construímos nos últimos trinta anos ao depor Dilma Rousseff e ameaçam invadir a Venezuela. Não se trata de combater a corrupção ou de amor à democracia, trata-se de controlar as reservas de petróleo mesmo.

7. No prefácio do livro "Dies Irae - Oito testemunhos indignados e uma ressurreição", sobre o poema "A memória do anjo", que trata do morte pelo aparato policial da Ditadura do estudante paulista Ruy Carlos Vieira Berbet, Pedro Casaldáliga assegura que o texto 'palpita com evocações e indagações de um Pedro Páramo." Como você se vê nesta alusão literária?

Honrado. Juan Rulfo será sempre uma das mais importantes referências da literatura neste continente. Sobre Pedro Páramo, Garcia Marquez afirma "se não a melhor, se não a maior, se não a mais importante, é sim a mais bela das novelas que jamais se escreveu em língua castelhana”. Gera com ela uma clara ruptura com a tradição novelística da América Latina. Não creio que a relação que faz Pedro Casaldáliga entre "A memória do anjo" e as "evocações e indagações de um Pedro Páramo" seja apropriada, talvez por excesso de generosidade.

8. O Padre Josimo foi seu colega de militância na defesa dos trabalhadores sem terra. Em homenagem a Josimo, você compôs o poema "A morte anunciada, de Josimo Morais Tavares". Este poema permanece atual por sua mensagem?

O Brasil é um país que anda em círculos. Os poetas em geral desejam ardentemente que suas obras permaneçam no tempo, se mantenham sempre atuais. Lamento profundamente que 
“A morte anunciada de Josimo Tavares" seja tão atual, confesso. Até quando o latifúndio, agora travestido com o nome contemporâneo de "agronegócio", seguir assassinando camponeses e seus companheiros de luta, Josimo seguirá sendo assassinado como naquele 10 de maio de 1986, em Imperatriz e esse poema se manterá atual, desafortunadamente.

\section{Em livros como "Passarinhar" e "Porto Submerso", você se debruça sobre o universo} da cultura e da geografia tocantinenses. Que ligação possível você faz entre esses dois livros e os demais?

Concluí, no último ano que "Passarinhar" e "O Porto Submerso" não são gêmeos univitelinos. São, um e outro, aproximações em tempos diferentes da minha gente e dos meus lugares. São um livro só. E trabalhei na revisão dos poemas, corrigi as repetições, recuperei poemas que deveriam estar lá e ficaram nos arquivos e os preparei para uma edição nova sob o título "O Porto Submerso". Agora, em busca de editor... Tenho carinho por esses poemas. Talvez, como conversávamos acima, eles me aproximem daquilo que Mestre Tristão de Athayde se referia quando mencionou Garcia Lorca. Há um aspecto neles que poderia ser resumido na metáfora que o próprio título carrega: "O Porto Submerso" se refere tanto à inundação física da paisagem da minha infância, quanto ao olvido, ao esquecimento dos personagens que submergiram na memória e busco sempre resgatar no meu verso.

O livro incorpora uma dimensão diferente ao abordar a nossa relação humana com o rio. O Tocantins ainda pede para ser contado em sua beleza e sua tragédia. Cobra dos escritores, dos poetas, dos músicos exporem os conflitos e as agressões que o matam a cada ano, ao encerrar cada ciclo das estações. O poema "Nascentes" deseja exatamente isso. Contar esse rio e o que fizemos dele.

10. Como foi a experiência de escrever e de conceber, em parceria com Pedro Casaldáliga, Milton Nascimento e Martin Coplas, as obras "Missa dos Quilombos" e "Missa da Terra sem Males"?

Conviver com um homem da estatura de Pedro Casaldáliga por si, já seria uma dádiva. Ter sido companheiro de muitas lutas e parceiro de trabalho na realização das duas Missas é mais do que esperava da vida... Conheci Pedro pessoalmente quando ele foi visitar os presos políticos no Carandiru, na Zona norte de S. Paulo, nos anos setenta. Ele já conhecia meus poemas e combinamos ali que ele faria o prefácio dos "Poemas do Povo da Noite", que ele 
depois traduziria para o espanhol. Confeccionamos e oferecemos a ele umas sandálias de couro sobre o solado de pneu. Escrevi há alguns anos o texto "Um par de sandálias para o peregrino" para homenageá-lo.

Aos noventa anos, por onde passa Pedro deixa marcas indeléveis. Penso que com as duas Missas contribuímos para oferecer uma expressão estética para as lutas seculares das comunidades indígenas e afrodescendentes do Brasil. Alguém ao comenta-las advertiu que a Teologia da Libertação não havia até ali criado uma "Liturgia da Libertação" que lhe correspondesse. A criação musical de Martin Coplas para a "Missa da Terra sem Males", sua pesquisa, os instrumentos originais que utilizou nos arranjos vestiram com beleza e suavidade o texto de denúncia e penitência. Quando encontramos Milton e ele topou compor a "Missa dos Quilombos" tivemos consciência de que estávamos diante de um dos maiores talentos da música popular brasileira, num dos momentos mais fecundos de sua vida criativa. Ele me disse numa ocasião que com a "Missa dos Quilombos" assumiu a inteira consciência de ser negro. Para alguém que não é exatamente religioso, foi uma experiência profundamente gratificante do ponto de vista da criação artística e do ponto de vista das lutas políticas pelas causas dos índios e dos negros.

\section{Você pensa em se dedicar também à prosa de ficção? Há algum livro em andamento?}

\section{Como o senhor vê a linguagem? Que recursos poéticos não "abre” mão de usar?}

Concluí nos últimos dias de 2018 um pequeno livro. Como é o mais recente por algum tempo será o mais importante... Pela primeira vez ficção em prosa. Uma experiência árdua. Imaginei produzi-lo em um ano. Levei três para concluir. São seis histórias curtas e levará por título "O pesadelo circular (Narrativas dos anos de chumbo)". Histórias imaginadas num país que anda em círculos... Uma experiência como essa me põe à prova. Como me afastar da linguagem poética que molda minha produção há tantos anos para me aproximar de um relato mais 'objetivo'? É um exercício de aprendizado e não estou muito seguro se alcancei o resultado desejado. O leitor dirá. Como nos livros anteriores, não posso abrir mão de recorrer à memória e à invenção, afinal, parafraseando Manoel de Barros: “Tudo que não invento, é falso..."

13. Em uma declaração sua o senhor afirmou o seguinte: "A poesia dispara mecanismos libertários porque subverte o real e assim desata as amarras da imaginação, da irreverência, abole o medo do coração dos homens e, por certo, das mulheres. $O$ medo, 
todos sabemos “... é uma gaiola dentro do peito". E por fazer frente a ele, por desafiá-lo, a poesia comove. No sentido antigo desse termo: mover com. Para além de produzir encantamento, produz ação coletiva". De que "tipo" de ação você está se referindo, poderia comentar/falar mais sobre essa questão?

Da ação coletiva, Lia. Da ação política, portanto. Estou convencido de que a poesia não é um instrumento muito apreciado por quem pretende derrubar governos. Mas não há tirania que não a tema... Na vida, quando optamos por um caminho para agir, os passos não derivam necessariamente de escolhas racionais prévias. Derivam em grande medida da emoção. Por isso a poesia, a arte precisam comover se desejam, conscientemente ou não, produzir ação. Um grande revolucionário do século XX afirmava que "a Revolução é um grande drama passional"... penso que ele tem razão. A poesia fascina porque é libertária, é irreverente, transgressora. Produz espanto. Nos devolve para a infância. Abole o medo paralisante. A poesia é irredutível ao poder. Por isso as tiranias a temem.

14. Sobre literatura e política, o que diria aos jovens estudantes dessa geração que estão nas escolas e nas universidades?

Mergulhem profundamente na cultura brasileira. Não há registro de resistência a qualquer tirania, que tenha alcançado êxito, que não tenha mobilizado o arsenal simbólico, cultural dos povos oprimidos que anseiam e lutam por liberdade. Mergulhem profundamente na História do Brasil para que possam entender melhor como nossa gente reage aos opressores. Os colonizadores antigos e modernos e sempre os senhores de escravos e seus descendentes. É indispensável entender as marcas profundas que trezentos anos de escravidão deixaram no caráter e nas relações sociais no nosso país. E como essas relações dissimulam a cultura patriarcal, autoritária e disseminam a hipocrisia como forma de sobrevivência social. Mas, sobretudo não permitam qualquer violação à sua liberdade. 
